August 2010

\title{
Denial of the Reality of State Terrorism in Argentina as Narrative of the Recent Past: A New Case of "Negationism"?
}

Mario Ranalletti

Follow this and additional works at: https://digitalcommons.usf.edu/gsp

\section{Recommended Citation}

Ranalletti, Mario (2010) "Denial of the Reality of State Terrorism in Argentina as Narrative of the Recent Past: A New Case of "Negationism"?," Genocide Studies and Prevention: An International Journal: Vol. 5: Iss. 2: Article 4.

Available at: https://digitalcommons.usf.edu/gsp/vol5/iss2/4

This Articles is brought to you for free and open access by the Open Access Journals at Digital Commons @ University of South Florida. It has been accepted for inclusion in Genocide Studies and Prevention: An International Journal by an authorized editor of Digital Commons @ University of South Florida. For more information, please contact digitalcommons@usf.edu. 


\title{
Denial of the Reality of State Terrorism in Argentina as Narrative of the Recent Past: A New Case of "Negationism"?1
}

\author{
Mario Ranalletti \\ Universidad Nacional de Tres de Febrero, Buenos Aires, \\ Argentina
}

This article applies the concept of negationism-from a French basis-to an analysis of the activities and discourse of groups and individuals who define the state terrorism applied in Argentina between 1975 and 1983 as a "war" against "Marxist subversion," in defense of "Christian and Occidental Civilization." By distorting history and systematically denying the reality of state terrorism, Argentine negationists try to disguise the vindication of state terrorism as a fight for the truth and memory. The article is organized in three parts. A brief review of the origins of this concept and of the negationist current in France is followed by a discussion of the differences between the concepts of revisionism and negationism. The gestation and historical evolution of this current are then analyzed and described; for this purpose, the article deals with some of the principal argumentations and tactics used by the negationists in their media appearances and street ceremonies: books, magazines, courses, conferences, literary gatherings, so-called study groups, Web sites, demonstrations, and public commemorations, claiming a "complete social memory," are employed to instill a revision of Argentina's recent past. Finally, the article deals with the current stage of the evolution of negationist groups.

Key words: negationism, Argentina, state terrorism, historical memory

To Pierre Vidal-Naquet, in memoriam

\section{Introduction}

For some, it is only a mental disorder. ${ }^{2}$ For others, like Pierre Vidal-Naquet, we are witnessing a current to which no publicity or relevance should be given, either by criticizing or by arguing against its absurd ideas; with the negationists, there is no debate of ideas but, rather, a political combat, whose center is Holocaust denial. ${ }^{3}$ According to Henry Rousso, creator of the neologism, negationism is an ideological system disguised as a "true" scientific approach. ${ }^{4}$ Applied to the Argentine context, this concept allows us to define the activity carried out by certain groups and individuals dedicated to manipulating the past for propaganda purposes-means and purposes that they share with local Catholicism and extreme right sectors. In no way or sense do I intend here to establish an analogy, comparison, or parallelism between the Nazi extermination experience and the experience of Argentine state terrorism through this extrapolation. ${ }^{5}$ This extrapolation and use of the concept of

Mario Ranalletti, "Denial of the Reality of State Terrorism in Argentina as Narrative of the Recent Past: A New Case of 'Negationism'?" Genocide Studies and Prevention 5, 2 (August 2010): 160-173. (C) 2010 Genocide Studies and Prevention. doi:10.3138/gsp.5.2.160 
negationism can, however, be justified as a proposal for discussion and as a theoretical exercise.

Either ignored or underestimated by academics, Argentine negationists constitute an amorphous group of political and cultural agitators, organized in a social network whose main activity consists of appearing in public trying to impose and/or question some event of the recent past. These groups or individuals fragment, mutate, regenerate into new groups or NGOs, and blend into society-in particular, into universities, the education system, and the legal system. Although there are no statistics or quantitative data on these individuals, their visibility and number seem to have been increasing since 1983 .

This article is organized in three parts. The first section presents a distinction between the concepts of revisionism and negationism, followed by a brief review of the origins of the concept and of the negationist current in France. The second part analyzes and describes the gestation and historical evolution of negationism in Argentina, highlighting their first demonstrations, the characteristics of the people involved in negationist actions, the discursive elements legitimating state terrorism employed to achieve their objectives, and the relation between all of these elements and the historical context in which they occur and develop. The third and final section presents an outlook for the current phase of the negationist venture.

\section{Revisionism Is Not Negationism}

Negationists resort to the term "revisionism" in an attempt to contextualize their actions within the scientific field; but the two views are radically different, both in their approaches to the object of study and in the aims that lead the researcher. A revisionist historian, theoretically, seeks to re-examine the past through rational procedures that follow rules and scientific and academic conventions. Revision, in this case, consists of a search whose main objective is for knowledge to progress. It is well known that revisionism has a political side, particularly, within Marxism. On the other hand, the negationist invents the object of study and produces his or her sources, disregarding basic premises of scientific research such as re-reading the existing bibliography, assessing sources, and scientific study of available documentation on the subject of interest. Negationism is limited to distorting available information and knowledge in order to earn the position of truth-possessor in the struggle for hegemony in representing the past. ${ }^{6}$ Negationists do not revise; rather, they invalidate and discredit-with purely ideological arguments-the testimonies of Nazism's victims and everything that has been discovered through research about the systematic extermination of people, groups, and communities carried out by the Nazis. ${ }^{7}$ Clearly, this is something more than just a "battle of words," as Valérie Igounet writes. ${ }^{8}$

Normally, the term "revisionist" can have many meanings: "apologist," "reactionary," "nationalist" (in the Argentine case). In this article, I take "revisionist" and "revisionism" as synonyms for an attempt to revise the available knowledge on a subject to contribute further information via scientific research. I do not use "revisionist" and "revisionism" as synonyms for "negationist" and "negationism"-a current use in the Anglo-Saxon world. Pierre Vidal-Naquet's assertion points to the difference between a scientific attitude and an anti-scientific attitude. ${ }^{9}$ It is true that revisionism can be negationism, but my approach in this section aims to differentiate revisionism as a scientific attitude on a historical matter from the assimilation of the terms "revisionism" and "negationism" that dominates studies of these questions in 
the Anglo-Saxon world. This distinction is more frequently made within French, Spanish, and Latin American academia.

For so-called revisionists, their main difference from negationism is their rapport with scientific knowledge and its rules. The fundamental principle of all revisionism-and not in the political sense-is the review of available knowledge. For example, revisionism promotes debate to confront ideas, points of view, and approaches and to exchange arguments. A revisionist historian does not discuss facts themselves but, rather, addresses their interpretation. Another fundamental difference lies in the distortion of the available knowledge about a subject. The revisionist does not ignore what he or she already knows about a subject but, rather, tries to modify the current interpretation by refuting this knowledge based on serious and scientific research.

For negationism, on the other hand, the goal is to deny the facts. The negationist tries to use the review of available knowledge on a given topic to deny the reality of the known facts. Thus, negationism constitutes a deliberate lie for political ends, which has nothing to do with interpreting the historical evidence, and which has become an apologia for a criminal political and social regime. The perfect example is Holocaust denial, which negationists claim is a question of "free speech."

\section{The Origins of Negationism in France}

The negationist view arose in the immediate post-World War II period and was initially a reformulation intended to adapt anti-Semitism, anti-Zionism, and antiCommunism to that context. This fabrication had its origins in the publication of Nuremberg ou la terre promise by Maurice Bardèche (1909-1998), ${ }^{10}$ in which the author, an extreme-right activist, rebelled against the "unfair" justice of the victorious Allied powers and accused them of fabricating the genocide of the Jews in order to mask their own crimes. ${ }^{11}$ This line of "analysis" was boosted by the diffusion of writings by Paul Rassinier (1906-1967)—ex-pacifist, ex-socialist, and exCommunist-whom negationists consider the first "revisionist historian." 12 Rassinier published a work titled Le mensonge d'Ulysse, in which he questioned the veracity of ex-deportees' testimonies about the existence and employment of gas chambers in the Nazi concentration camps. Considered by the experts as negationism's foundational text, ${ }^{13}$ Rassinier's book trivializes the matter of the gas chambers: though not stating directly that they did not exist, he minimizes their relevance, questioning the prevailing version of history in order to free Nazism from its exterminating character.

Rejected by every current he had frequented until then, Rassinier became a "divine surprise" for the extreme right. Bardèche, the propagandist Henry Coston (1910-2001), and the magazines Rivarol and Défense de l'Occident defended and promoted him as the living testimony of "truth," "denied" and "persecuted" by the victorious powers. This is the tone of what is considered the first period of negationism, which extended from 1948 to 1967. Rassinier's death in 1967 marked the onset of a new period in the history and evolution of negationism in France; since then, defense of the Palestine cause has become the core of negationist activism, exploited to reintroduce anti-Semitism into public debate.

The beginning of the third stage is determined by the so-called affaire Faurisson in 1978. Robert Faurisson, a professor of twentieth-century French literature at Université Lyon II, shocked the academic and media worlds by circulating a letter, addressed to hundreds of figures worldwide, in which he outlined-with "scientific" arguments-his doubts about the purpose attributed to the gas chambers. Initially, 
he succeeded in attracting the attention of major French media-Le Monde, Le Canard enchaîné, L'Express, and the radio station Europe 1 -but in the debates that followed, Faurisson rose from obscurity to a place in the field of Nazism. The debate abruptly closed, and Faurisson was "rescued" by Bardèche and Défense de l'Occident, a publication that embraced with enthusiasm Faurisson's "revisionist" and "scientifically" supported theses. His main argument alleged that there is no documentation proving that the gas chambers were used to kill people, nor to certify that Hitler ordered the Final Solution. Faurisson concluded that his assertions were "good news" for humanity, which was thereby freed from this opprobrious event. ${ }^{14}$ His views prompted widespread condemnation, and he was dismissed from his university post. Following this incident, the focus of attention moved outside France with the organization of an international campaign to defend Faurisson in the name of "freedom of speech," of which Noam Chomsky was one of the main supporters. ${ }^{15}$

All this ideological and media agitation met a favorable reception in some libertarian, extreme-left, and anarchist circles-such as the Anarchist Federation and the bookstore and publishing house La Vieille Taupe-in which anti-Zionism tends to be confused with anti-Semitism and underlies Third World and anticapitalist perspectives. For these marginal but vocal groups, the negationist attempt to rewrite history is a practical way to channel the repressed anti-Semitism of many of their members. ${ }^{16}$ It was during this period that Jean-Marie Le Pen's extremist National Front, a political party always supportive of and receptive to the negationist view of the world, reached its first peak of popularity in France. The experts consider Faurisson's intervention responsible for the radicalization ${ }^{17}$ and simultaneous stylization of the negationist fundamentals and discourse, relative to the first steps taken by Bardèche and Rassinier.

One of the last events in this chapter of the history of negationism in France was the scandal over the doctorate in history obtained by agronomist Henri Roquès at the University of Nantes in 1985. Roquès obtained his diploma by forging administrative documents and establishing a biased dissertation committee. ${ }^{18}$ In his dissertation-and following Faurisson-Roquès introduces himself as a "scientist" who breaks down and refutes the testimony of Kurt Gerstein, an SS officer captured and interrogated by French officers. Gerstein's statements had been taken, until that moment, as irrefutable proof of the existence and employment of gas chambers in the extermination of people at the hands of the Nazis. Another salient aspect of Roquès's doctoral dissertation was his complaint-he pointed to his own work as an example-that the "revisionist school" should obtain full admission to the academic historiography. The following year, Roques's fraud was discovered, and his diploma was withdrawn-an unprecedented event in the history of French higher education. ${ }^{19}$

\section{Argentine Negationism: Characteristics, Origins, and Development}

Negationism is a marginal sector of the Argentine political and cultural spectrum. Several different stages can be identified, each having particular characteristics with respect to the people involved, the subjects dealt with, and the political and communicative strategies employed. The shortage of followers is compensated for by the movement's important involvement in almost every sphere from which indoctrination or propaganda can proceed: the mass media, the justice system, legal advice, public and denominational education, bookstores, the Catholic Church, the army, and the security forces. Books, magazines, courses, lectures, spiritual retreats, literary circles, study groups, Web sites, marches, masses, media interventions, and 
public demonstrations in the name of a "complete" memory are some of the tools deployed to convince the audience that researchers' work on memory and the consequences of state terrorism in fact constitute a campaign to undermine the prestige of the armed forces. Following this syllogistic reasoning, current judicial proceedings against military and security personnel, as well as civilians, for their participation in state terrorism are the result of such a campaign. It is worth mentioning that the theses and interpretations of the negationist movement are diffused far beyond the smaller circle of its activists and adherents.

The core of the negationist line of argument consists in defining the state terrorism applied in Argentina as a supposed war, against "revolutionary" or "subversive" elements. With this distortion of the past-for Argentina, the only war in the twentieth century was the Malvinas/Falklands conflict-negationists seek to exonerate the perpetrators of state terrorism from their crimes and vindicate their actions during the repression of the popular activation ${ }^{20}$ that the country experienced toward 1975. Following Faurisson's example, they seek protection in the right to freedom of speech, currently adding a demand-apparently devoid of any particular interest-for completion of memory and information about the recent past. In accordance with these arguments, local negationists seek to establish themselves as the bearers of "another" version of Argentina's recent history, "true" and different from that supported by human-rights organizations, as well as by two governments (2003-2009), and emerging from several current judicial processes against individuals involved in the application of state terrorism, characterizing the latter version with adjectives such as "false" and "tendentious."

Another remarkable feature of the Argentine negationist movement is its ability to build networks of solidarity and friendship, which are fundamental for diffusing materials and slogans. In order to achieve this goal, negationists use three main channels: the Internet, radio, and cable television. Currently, they have shown their intention to occupy the public space with direct interventions-such as open demonstrations, commemorations included in a settled calendar, and escraches. ${ }^{21}$

The origins of Argentine negationism should be placed toward the end of the last de facto government, although some earlier precedents can be pointed out. The starting point for this way of seeing the recent past in Argentina is the use of the concept of "war" to characterize the present situation. Such an interpretation is not exclusive to negationists, as it has been included in the Argentine political culture since at least $1955 .^{22}$ The representation of the present as a war implied an erroneous interpretation of the Argentine reality, used to conceal the growth of social inequality, on the one hand, and the proscription and persecution of the majority party, on the other hand, as the causes of the violence that the country was experiencing.

The last de facto government ${ }^{23}$ appropriated this interpretation, used it to justify their existence, and built it to a paroxysm by presenting it as the core of their political propaganda. ${ }^{24}$ The military members of the government took the first steps toward institutionalizing this account of the recent past, structured on the basis of the notion of war, as the report El terrorismo en la Argentina ("Terrorism in Argentina") testifies. ${ }^{25}$ In this report, which was widely distributed, particularly at the level of public education, the de facto government presented ample journalistic and official information magnifying the growth and combat capacity of several guerrilla organizations in order to support their interpretation of the contemporary situation. This first attempt was reinforced by the intervention of the Argentine Catholic Church's Episcopal Conference, which, although it defended the idea of 
reconciliation among the Argentine people, confirmed that the country had left behind a sort of civil "war," defined as "the evil of guerilla violence." 26

A short time later, in the context of Argentina's defeat in the Falklands war ${ }^{27}$ and with a settled date for elections, the de facto government continued advancing in this direction, announcing the so-called Final Report of the Military Junta on the War Against Subversion and Terrorism, which formed the basis for the "National Pacification" law (law no. 22.924, passed in March 1983 and published in the Official Bulletin of 27 November 1983). This regulation declared that every possibility of criminal prosecution of individuals who had committed crimes "with terrorist or subversive motivation or purpose, between 25 May 1973 and 17 June 1982" had expired. The benefits provided by this law extended also to "every action of a criminal nature executed on the occasion of or to develop actions aimed at preventing, averting, or ending the said terrorist or subversive activities, whatever its nature or the injured legal rights may have been." 28

This legislation motivated a new intervention by the Catholic Church through the Episcopal Conference Standing Committee. This organization issued a document titled "Path to Reconciliation," which communicated to citizens the Church's official position regarding the defeat of the de facto government: this was not the time to revise the recent past but a time of reconciliation for all Argentine people. The term "war" was used in this document, but it referred to the war recently fought to recover the Islas Malvinas (Falkland Islands) from the United Kingdom.

If the military government and the Catholic Church were the first entities to suggest that state terrorism had actually been a war, the first efforts from within Argentine society to follow this path came from a civilian association created in 1979, whose purpose was to pay tribute and commemorate the military and security men who had died in this so-called war against "subversion." Adopting the name Familiares de Muertos por la Subversión, or FAMUS ("Relatives and friends of the dead by subversion"), this association concentrated on celebrating religious ceremonies and publishing the newsletter Tributo. FAMUS, dissolved almost twenty years ago, ${ }^{29}$ combined negationist propaganda with the vindication of the right to social recognition of the dead, victims of actions conducted by armed organizations during the 1970s. Between 1984 and 1985, negationism began to gain visibility as an opponent group in the dispute over determining the generally accepted account of the past, with its public demonstrations against investigations into the consequences of state terrorism and, in particular, its fierce opposition to the trials of the military juntas that governed the country between 1976 and 1983. ${ }^{30}$ Subsequently, the "Nunca Más" report, the judgment of the Federal Court concerning former military juntas' commanders in chief, the "Full Stop" and "Due Obedience" laws, and the presidential pardons of 1999 and 2000 reinforced, in different ways, the explanatory power of characterizing the recent Argentine past as a war. ${ }^{31}$

\section{Incorporating the Memorial Register in the Negationist Fight: The Question of "Complete" Memory}

In this way and by these means, the representation of the recent past as a "war" managed to solidly settle within the Argentine society, offering the negationists a context favorable to spreading their theories. The progressive consolidation of a democratic system in Argentina benefited the emergence of debates about the past and about state terrorism, in which the notion of "war" was the strong point in the negationists' argument. Faced with the progress of judicial investigations into 
the consequences of state terrorism, the negationists were compelled to intervene to refute stories and memories that did not subscribe to the notion of "war" as the organizing myth of the recent Argentine past.

Argentine negationism reproduces quite faithfully the French matrix described above. The Argentine negationists' approach is similar to that of their French counterparts; the local impact of authors such as Bardèche, Rassinier, and Faurisson surpasses that of any other negationist-David Irving excluded. The key here is the strong presence of French intransigent Catholicism, a true driving force of French reactionary thought in Argentina, in Irving's work. The existence of a niche of extremist activists in this country who also nourish themselves on Mediterranean reactionary thought is one reason for the dominance of the French model on the subject, as shown in the work of Sandra McGee Deutsch, Ronald Dolkart, Cristián Buchrucker, and Daniel Lvovich. ${ }^{32}$ When faced with voices that conflict with their own view of the world and their own interpretation of the past, negationists first act to discredit those statements by labeling them as inventions or as responses to an implicit or explicit political intent. This was the case in what could be considered the first local negationism event: the publication and media diffusion of the book La otra campana del "Nunca Más" ("The other truth of "never again"), written by Miguel Osvaldo Etchecolatz, a former captain in the Buenos Aires Police Department and former director of investigations on that force (1976-1977). In 1997, following the launch of his book at the Buenos Aires Book Fair, Etchecolatz embarked on a campaign to denounce the final CONADEP report, ${ }^{33}$ describing it as a "lie" and an invention of the perpetuators of the "subversive war." Confined to extreme-right bookstores, this book had better luck on public television, ${ }^{34}$ although its impact created a certain discomfort in the audience and minimized the positive effects expected for the negationist cause.

This was the trend of what could be considered the first moment of a fully constituted negationism, during which those involved in the implementation of state terrorism were themselves the principal agents in campaigns conducted to establish their views about the past within society. With the sanction of presidential pardons ${ }^{35}$ and the subsequent reactivation of trials and judicial investigations on the consequences of state terrorism, this stage-governed by the direct intervention of perpetrators and by failed attempts to refute the investigations undertaken into the consequence of state terrorism-found its closure. Since 2000, the center of gravity has begun to shift from the invalidation of state terrorism toward a pretended "duty to memory."

The first sign of this change was apparent in an event that combined the main characteristics of both stages. An official association of retired military personnel, the Argentine Army Military Association, decided to publish a large-scale work in which interventions by those responsible for applying state terrorism were combined with a strong demand for legal registration of those dead as a result of actions by guerrillas in the pantheon of those fallen in the supposed "war." This book, titled In Memoriam, was first published in 1998 and completed by two more volumes; it again uses the notion of war, although introducing what was certainly novel: the idea that the "war" continued and must now be fought on the level of collective memory, as the chosen title clearly indicated.

\section{The Renewal of Negationist Personnel}

This modification in both the communicative strategy and the content of Argentine negationist discourse is accompanied by another, also significant, whose con- 
sequences and evolution are difficult to measure: a generational renewal in the ranks of negationism, nurturing young professionals to continue what they preach. The inclusion of a new, younger cohort of activists-many of them university educated, and not all of them belonging to the military environment-has given a new boost to negationist activism.

With respect to discourse content, newer groups and propagandists no longer work only on characterizing the 1970s as a "war"; instead they deal with a variety of topics: vindicating and/or comparing the memory of guerrilla actions' victims with those who suffered under state terrorism; impugning judicial proceedings against military and security personnel; reconstructing a "complete memory," a search for the historical "truth" to confront state manipulation; organizing campaigns to discredit government officials for their political background; progressively replacing the term "subversion" with the term "terrorism"; and denouncing the political nature of the current version of 1970 s history. Probably the most significant factor in this new stage of negationism, with respect to its objectives, is the attempt to include in the national calendar a commemorative day for persons killed by the actions of guerrilla organizations.

The focal point of negationist efforts during the past decade has shifted toward the sphere of memory. Their demand is presented as neutral and legitimate, which is its main attraction for their audience. Thus it could be appreciated in the declaration of principles of one of the "stars" in this new phase of Argentine negationism: the association Argentinos por la Memoria Completa (in English, "Argentineans for a Complete Memory"). In the "About Us" section of their Web site, they presented themselves as a "group of young Argentineans" united by a common interest in 1970s Argentine history to connect via the Internet with "citizens throughout the country who feel the necessity of expressing their gratitude to those who fought subversion and terrorism." Their eruption onto the political scene took place when they published on their Web site a letter written by the former general Reynaldo Benito Bignone, and addressed to "the youth," in October 2006. In this document, the last president of the "national reorganization process" called on the new generation to become modern "idealists" who-just like the revolutionaries of May 1810-would rise against adversity in order to finish "what we were not able to finish." 36

This association promoted another figure of the "new negationist wave" in Argentina: the lawyer Nicolás Márquez, born in 1975 in Mar del Plata, a city in the province of Buenos Aires. Author of two bestsellers, ${ }^{37}$ he represents his written work as an "objective" view on the recent past, free of personal ambition. Márquez has taken care to attack the condemnation of state terrorism not only in classic local negationist terms but also by resorting to legal arguments such as impugning Argentina's accession to the Rome Statute of the International Criminal Court, which legislates on crimes against humanity.

Those groups that promote "complete memory" have attempted to install in the national calendar of celebrations a day for "victim of guerrilla terrorism," to be observed on 5 October. The chosen date corresponds to the combat between the army and the guerrilla organization Montoneros, which assaulted the 29th Infantry Regiment in the province of Formosa. Argentinos por la Memoria Completa called for remembrance of the "dead by subversion," a practice repeated since 2001. At present, it is the Centro de Estudios Legales sobre el Terrorismo y sus Víctimas, or CELTYV (in English, "Center for Legal Studies on Terrorism and Its Victims"), 38 that continues the campaign to include the "National Day of the Victims of Terrorism" on the official calendar. Their campaign consists of mass demonstrations 
in Plaza San Martín, a central square in the city of Buenos Aires, with both civilian and military speakers: the leitmotiv is "know the victims of terrorism." During the first week of every October, publicists and militants from CELTYV and Memoria Completa participate in political media programs-such as Hora Clave, hosted by journalist and university professor Mariano Grondona-to publicize their activities and public demonstrations during that week. ${ }^{39}$ These campaigns receive important support from La Nueva Provincia, the most important daily newspaper in the province of Buenos Aires, whose strategy is to reproduce the political and judicial actions carried out by the associations that seek justice for the victims of state terrorism. CELTYV tries to be the opposite number of the Centro de Estudios Legales y Sociales, or CELS (in English, "Center for Legal and Social Studies"), one of the most important human-rights organizations in Argentina and throughout Latin America.

Another figure who regained visibility in the context of this renewal of Argentine negationism is the journalist Juan Bautista "Tata" Yofre, director of the Secretariat of State Intelligence (SIDE) during Carlos S. Meném's first administration. A series of books that achieved great sales success, in which Yofre suggests understanding state terrorism as a "low-intensity war" and an unavoidable response to the violence carried out by armed organizations, is the outcome of his pen and of his trajectory through SIDE. ${ }^{40}$ In his books, Yofre constantly highlights the magnitude of the violence carried out by guerrilla groups and stresses that it occurred within a constitutional context; his aim is to exculpate General Juan Perón's last government and the armed forces with respect to the application of state terrorism as a means to put an end to the political violence experienced in Argentina toward 1976. His argument is-conscious or unconsciously-a restatement of the "theory of the two demons," which, in Yofre's case, serves the ends that negationism pursues: according to his reasoning, state terrorism is converted into a sort of sought and deserved punishment. ${ }^{41}$

One of the most recent additions to the ranks of negationism is CELTYV (mentioned above), presided over by the lawyer Victoria Villarruel. This entity tries to reproduce the model of its Spanish almost-namesake, the Asociación Víctimas del Terrorismo ("association of victims of terror"), which focuses on the consequences of the actions of the armed Basque group ETA. CELTYV presents its raison d'être and its activities as a response to the needs of victims of guerrilla violence during the 1970s; its activities focus on seeking comparability between victims of state terrorism and victims of actions by guerrilla organizations, particularly with respect to legal recognition in pursuit of legal reparations. Along with organizing and sponsoring various commemorative events in honor of those vindicated as their "own" dead, CELTYV provides legal advice and encourages its members to launch lawsuits against the state demanding compensations for the loss of their relatives and friends in what they have defined as the "war against subversion." The activities of this association corroborate the changes pointed out above: by prioritizing the definition of terrorism, CELTYV restores the de facto government's initial characterization, in its report El terrorismo en la Argentina, in assessing repressive state actions.

Another recent arrival to the negationist dispute-also confirming the trend of renewal mentioned above-is Leandro Viotto Romano (b. 1985), a young law student at the Instituto Universitario de la Policía Federal Argentina (University Institute of the Argentine Federal Police) who is linked to national deputy Nora Ginzburg of the Frente por los derechos ciudadanos (a group detached from the RECREAR party). 
Advising this legislator on commissions on criminal legislation and internal security, Viotto Romano is the author, among other minor works of the same tone, of the book Silencio de mudos. La subversión en Argentina (1959-2005) de las armas al poder institucional y politico (in English, "Silence of the Deaf: Subversion in Argentina (1959-2005), from Arms to Institutional and Political Power"). Following a first selfpublished edition, the book was republished by Dunken and, according to Viotto Romano, has since gone through five more editions. In this case the negationist proposal is radicalized, freed from any demand of memory. According to the back cover of Silencio de mudos, the text

debunks the myth of the 30,000 disappeared, unmasks the real violators of human rights, and exposes the current Kirchnerist public servants who, in certain circumstances, did not hesitate to rise up against constitutional governments. Other extreme-left personages such as Hebe de Bonafini and Estela Carlotto are not excluded from the analysis in this book. ${ }^{42}$

For a partial list of Argentinean negationist Web sites see Table 1.

Table 1: Some Argentine negationist Web sites

Organization URL

Movimiento por la Verdadera Historia

("Movement for true history"), established in 2008

Asociación de familiares y amigos de los presos políticos de Argentina ("Associahttp://www.verdaderahistoria.com/ blog/?paged=2

http://afyappa.blogspot.com/ tion of relatives and friends of Argentine political prisoners”), est. 2006

Unión de Promociones ("Union of promotions"), est. 2005

Asociación de Abogados por la Justicia y la Concordia ("Lawyers' association for justice and concord"), est. 2006

B1. Vitamina para la memoria de la Guerra en los '70 ("B1: Vitamin for the memory of the war in the 1970 s"), est. 2007

Comisión de homenaje permanente a los muertos por la subversión ("Permanent commission to honor the dead by subversion"), est. 2006

La historia paralela ("Parallel history"), est. 2006

La botella al mar ("Message in a bottle"), est. 2000

La caja de Pandora ("Pandora's box"),

http://www.energyworld.org/UP/

http://www.justiciayconcordia.org/

http://b1memoria.blogspot.com/ date unknown

http://energyworld.org/anita/index.htm

http://www.lahistoriaparalela.com.ar/

http:/www.labotellaalmar.com.ar/

http://www.lacajadepandoraonline.com/ 


\section{Some Preliminary Conclusions}

Manipulating the past for political purposes is a long tradition in Argentina. Revisionists of all kinds have used this resource to captivate their audiences-in uniform or out of it-particularly in periods of crisis. Nevertheless, what I have here called "Argentine negationism" goes beyond the boundaries of any revisionism. During the stage that Argentina is currently going through, the disputes supported by local negationists are part of their fierce opposition to current efforts at discovering the fate of many detained-disappeared people. Argentine negationism is, in this sense, an attempt to obstruct the job of judging and punishing the perpetrators of state terrorism. To reverse the judicial situation of many military personnel and members of the security forces for their involvement in crimes against humanity is - currently - the ultimate goal of Argentine negationist activism.

"A small but fierce sect," to adopt a definition by Pierre Vidal-Naquet, Argentine negationism also tries to appropriate historical description of the $1970 \mathrm{~s}$ in order to provide another element that facilitates the exculpation of perpetrators of state terrorism before society. From a macro-structural view, the epiphenomenon that local negationism embodies presents itself as a sample of how Argentine society relates to this past, at the same time traumatic and recent.

For the above-mentioned reasons, I consider that in Argentina, in the case of misrepresentation of the recent past as "war" instead of state terrorism, we cannot speak about "revisionism"; but we can extrapolate the notion of negationism to characterize the groups and individuals who argue that in the 1970s Argentina was waging a war against "communism" and that the government's crimes against humanity were committed during this war, or that they did not exist ("It is a lie of those defeated in the 'war"'). These groups are not revisionists; rather, those whom I have called "negationists" do not investigate the past to build their narrative of the recent past but, instead, use all possible means to install their version of history and to deny the reality of state terrorism.

The revision of the immediate past implies a job in which historians should become even more involved. The life and work of Pierre Vidal-Naquet constitute an example of how to tackle the question of negationism from within the discipline of history; they also show the professional and political path that we should follow as historians. Whatever the historical and social context may be, manipulation and distortion of the past represents nothing more than a political response to a series of historical problems. Fortunately, the truth is indestructible, in spite of negationists. ${ }^{43}$

\section{Notes}

1. A previous version of this paper was presented at panel no. 76, "Uses of the Past in Argentina: Historiographic Production and Collective Debates over National History (19th and 20th centuries)," of the XII Interschool Conference of History Departments, held at Universidad Nacional del Comahue (San Carlos de Bariloche, Río Negro) on 2831 October 2009. I would like to thank Alejandro Cattaruzza for his comments, which helped me to improve this work.

2. Valérie Igounet, Histoire du négationnisme en France (Paris: Éditions du Seuil, 2000); Martine Aubry and Olivier Duhamel, Petit dictionnaire pour lutter contre l'extrême droite (Paris: Éditions du Seuil, 1995), s.v. "Négationnisme."

3. Pierre Vidal-Naquet, Los asesinos de la memoria, trans. León Mames (Mexico City: Siglo XXI Editores, 1994). 
4. "The great audience discovers [in 1978] the suspicious means of the 'revisionists,' a qualifier they ascribe to themselves with impunity: the revision of history being a traditional method for scientists, herein we prefer the barbarism-less elegant but more appropriate-'negationism,' as it is a system of thought, an ideology, and not a scientific, or simply critical, process." Henry Rousso, Le syndrome de Vichy. De 1944 à nos jours (Paris: Éditions du Seuil, 1990), 176. Unless otherwise stated, all English translations are my own.

5. For an in-depth analysis see Daniel Feierstein, El genocidio como práctica social. Entre el nazismo y la experiencia argentina (Buenos Aires: Fondo de Cultura Económica, 2007).

6. Rousso, Le syndrome de Vichy, 14; Pier Paolo Poggio, Nazismo y revisionismo histórico (Barcelona: Ediciones Akal, 2006), 81-95.

7. Pierre Milza, "Le négationnisme en France," Relations Internationales 65 (1991): 9-22.

8. Igounet, Histoire du négationnisme en France, 14-5.

9. Vidal-Naquet, Los asesinos de la memoria (see note 3 above).

10. Maurice Bardèche, Nuremberg ou la terre promise (Paris: Les Sept Couleurs, 1948).

11. For reasons of length, I deal here only with the origins and development of negationism in France. This approach must be completed by consideration of its ramifications in North America, Great Britain, Germany, and some Arab countries. Arthur Butz, Germar Rudolf, Ernst Zündel, Ahmed Rami, and David Irving should at least be mentioned as continuers and disseminators of these theses outside France, which are not analyzed here.

12. Rassinier, a high school teacher, was arrested by the Gestapo, deported, and tortured, and was released after a year of imprisonment, almost completely disabled. See Gisèle Sapiro, "Le négationnisme en France," Revue de synthèse (5th ser., 2004): 217-28.

13. Paul Rassinier, Le Mensonge d'Ulysse. Regard sur la littérature concentrationnaire (Bourg-en-Bresse, France: Éditions Bressanes, 1950). On Rassinier see Vidal-Naquet, Los asesinos de la memoria, 54-60; Florent Brayard, Comment l'idée vint à M. Rassinier. Naissance du révisionnisme (Paris, Fayard, 1996); Nadine Fresco, Fabrication d'un antisémite (Paris: Éditions du Seuil, 1999).

14. Robert Faurisson, "Le 'problème des chambres à gaz," Défense de l'Occident, June 1978, $33-9$.

15. Vidal-Naquet, Los asesinos de la memoria, 92-102.

16. Igounet, Histoire du négationnisme en France, 457-88.

17. Nadine Fresco, "Négationnisme," in Encyclopædia Universalis (2004), http://www.universalis.fr/corpus2-encyclopedie/117/0/C010139/encyclopedie/

NEGATIONNISME.htm (accessed 2 June 2010).

18. The dissertation was removed from the history department of a Parisian university and transferred to the French department in Nantes, where the members of Roquès's defense committee were not experts in history, were personally related to the candidate, and, in two cases, were extreme-right activists. For further information on the affaire Roquès see Igounet, Histoire du négationnisme en France, 407-20.

19. For reasons of length, the outline offered here is incomplete. There have since been other incidents that demonstrate the survival of negationism in France. One of the most resonant had its epicenter, once again, at the University of Lyon; this time it was a professor of literature and Japanese culture who supported and encouraged anti-Semitic and negationist research. The French government gave the historian Henry Rousso the task of investigating this case and, based on Rousso's report, decreed the dismissal of the professor, who was an important member of the National Front.

20. This is an incipient discussion within academia, and, in this article, neither the word "revolution" nor any of its derivations is used to characterize the 1970s in Argentina. Guillermo O'Donnell suggests the category of "popular activation" to define the combination of social protest and armed protest as generators of violence within the framework of a long proscription (1955-1973) of the majority party in Argentina. María José Moyano has reintroduced, expanded, and developed this approach. See Guillermo O'Donnell, 
1966-1973. El Estado burocrático autoritario. Triunfos, derrotas y crisis (Buenos Aires: Editorial de Belgrano, 1982); María José Moyano, Argentina's Lost Patrol: Armed Struggle 1969-1979 (New Haven, CT: Yale University Press, 1995).

21. Describing a type of demonstration inaugurated by human-rights organizations in Argentina that consists of publicly denouncing a certain person-generally in that person's presence-the word escrache comes from the local argot, known as lunfardo.

22. Various propagandists for intransigent Catholicism and the extreme right, as well as adherents of traditional political parties, have found in the increasing number of social demonstrations and, particularly, of armed demonstrations a verification of this diagnosis. This interpretation had been assimilated by a large proportion of future perpetrators of state terrorism, who had been trained according to this ideological framework between 1955 and 1976; see Mario Ranalletti, "Contrainsurgencia, catolicismo intransigente y extremismo de derecha en la formación militar argentina. Influencias francesas en los orígenes del terrorismo de Estado (1955-1976)," in Terrorismo de Estado y genocidio en América Latina, ed. Daniel Feierstein, 253-84 (Buenos Aires: Prometeo Libros, 2009). For a study of political violence between 1969 and 1979 see Moyano, Argentina's Lost Patrol, ch. 6.

23. 24 March 1976-10 December 1983.

24. For examples of this campaign, taken from print and radio media, see Eduardo Blaustein and Martín Zubieta, Decíamos ayer. La prensa argentina bajo el Proceso (Buenos Aires: Ediciones Colihue, 1998), 76-155.

25. El terrorismo en la Argentina (Buenos Aires: Poder Ejecutivo Nacional, 1979-1980).

26. Conferencia Episcopal Argentina, "Los últimos tiempos," in Iglesia y Comunidad Nacional (Buenos Aires: Editorial Claretiana, 1981). This document represents the sixty-second full meeting of the Episcopal Conference, held on 4-9 May 1981. For a better and more complete study of this subject see Horacio Verbitsky, Doble juego. La Argentina católica y militar (Buenos Aires: Editorial Sudamericana, 2006).

27. 2 April-14 June 1982.

28. Law no. 22.924, 23 March 1983, art. 1.

29. In 1991, serious financial problems compelled the organization to cease its operations.

30. On these historical processes see Carlos Santiago Nino, Juicio al mal absoluto (Buenos Aires: Ariel, 2006); Jaime Malamud Goti, Terror y justicia en Argentina: Responsabilidad y democracia después de los juicios contra el terrorismo de Estado (Buenos Aires, Ediciones de la Flor, 2000).

31. On this subject see Mario Ranalletti, "Apuntes sobre la construcción del relato de la historia argentina reciente en el cine (1983-1989)," Film-Historia 8, 1 (1999): 3-16.

32. Sandra McGee Deutsch and Ronald H. Dolkart, eds., The Argentine Right. Its History and Intellectual Origins, 1910 to the Present (Wilmington, DE: SR Books, 1983); Sandra McGee Deutsch, Counterrevolution in Argentina, 1900-1932: The Argentine Patriotic League (Lincoln: University of Nebraska Press, 1986); Cristián Buchrucker, Nacionalismo y peronismo. La Argentina en la crisis ideológica mundial, 1927-1955 (Buenos Aires: Sudamericana, 1987); Daniel Lvovich, Nacionalismo y antisemitismo en la Argentina (Buenos Aires: Javier Vergara Editor, 2003).

33. CONADEP is the Spanish acronym for Argentina's National Commission on the Disappearance of Persons.

34. One of the most-watched TV programs at the time invited Etchecolatz to present his book on air. In front of him the host seated national deputy Alfredo Bravo, one of the detaineedisappeared.

35. In 1989-1990, Argentina's then president, Carlos Saúl Menem, announced a series of pardons (a total of ten decrees sanctioned between 7 October 1989 and 30 December 1990) that benefited almost 3,000 people, mostly civilian, military, and security men involved in the application of state terrorism. Decrees 1002, 1003, 1004, and 1005, dated 7 October 1989; Decrees 2741, 2742, and 2743, dated 30 December 1990. 
36. Before an investigation program discovered the damaging information that the association's president, Karina Mujica, practiced prostitution, Argentineans for a Complete Memory appeared in a more virulent way, including on its homepage a reminder that (retired) commandant Ricardo Miguel Cavallo was "illegally detained in Spain" and that his detention threatened national sovereignty. The homepage stated that the association's efforts were "dedicated to the men and women who during the 1970s wore a uniform to defend the Fatherland. As we have collected the blood of our martyrs to raise the Argentine flag, and because we are committed to our prisoners of war, for them we light today this memory flame-the flame of recognition and pride of a people-the flame that will never fade out" (Argentinos por la Memoria Completa, http://www.memoriacompleta.com.ar). Argentinos por la Memoria Completa has since moved to Facebook (http://www.facebook.com/group.php?gid=13770870034, accessed 7 June 2010). For an account of the Mujica affair, see Lorena Basani, "La doble moral, según Rolando Graña," Clarín, 20 September 2006.

37. Nicolás Márquez, La otra parte de la verdad (2004); Nicolás Vázquez, La mentira oficial. El setentismo como politica de Estado (2006). Both these books were self-published. They can be found in privileged positions in several bookstores, a sign of a significant sales volume. In 2008 Vázquez published El Vietnam argentino. La guerrilla marxista en Tucumán, with a prologue by Rosendo Fraga, Jr. On Márquez's work see Marcos Mayer, "Contradicciones de la Memoria Completa," Clarín, 30 December 2006, 3; Germán Ferrari, Símbolos y fantasmas. Las víctimas de la guerrilla: de la amnistía a la "justicia para todos" (Buenos Aires: Editorial Sudamericana, 2009).

38. CELTYV, http://www.victimasdeargentina.com (accessed 7 June 2010).

39. Grondona is one of the fiercest defenders of the "completed memory" position, that is, the recognition of the same status for victims of guerrilla violence, characterizing these crimes as crimes "against humanity." In an article for the conservative newspaper La Nación, he defends this position based on the case of two sisters whose identity was changed when their parents were murdered by perpetrators of state terrorism and they were "adopted" by a foster family, which meant the denial of their identity over a period of decades. The work of the associations Mothers of May Square and Grandmothers of May Square revealed this crime. When the truth became known, the two sisters had very different reactions: one decided to break with their foster family; but the other did not accept the truth and became a negationist activist. See Mariano Grondona, "Las hermanas Donda," La Nación, 7 October 2009, http://www.lanacion.com.ar/nota.asp? nota_id=1183418 (accessed 4 June 2010).

40. After successfully self-publishing the first edition, Yofre was offered a contract by Random House, while the publishing imprint Sudamericana republished the first volume of his work on the 1970s and published those that followed. The titles are as follows: "Nadie fue." Crónica, documentos y testimonios de los últimos meses, días y horas de Isabel Perón en el poder (1st ed., 2006); "Fuimos todos." Cronología de un fracaso, 19761983 (2007); and Volver a matar. Los archivos ocultos de la "Cámara del terror" (19711973) (2009). Yofre continues the line of argument opened by journalist Carlos Manuel Acuña, although with much more media success, beyond the boundaries of negationists and extreme-right groups.

41. "The theory of the two demons" (in Spanish, teoría de los dos demonios) is a political interpretation of the 1970s in Argentina, promoted by the government in 1983-1985 with great success. According to this interpretation, the political violence and state terrorism experienced by the country during those years were the result of a clash between two extremisms ("the two demons")— the military and the guerrillas—in which civil society was not involved.

42. Leandro Viotto Romano, Silencio de mudos. La subversion en Argentina (1959-2005) de las armas al poder institucional y politico (Buenos Aires: Editorial Dunken, 2005).

43. Vidal-Naquet, Los asesinos de la memoria, 13. 